\title{
Spectrul epidemiologic, clinic şi evolutiv al cazurilor de rujeolă internate în Spitalul Clinic de Boli Infecțioase și Tropicale „Dr. Victor Babeş“ din Bucureşti în cursul epidemiei actuale
}

\author{
Geta Vancea ${ }^{1,2}$, Andreea Stoenescu', Irina lanache ${ }^{1}$, Cristina Iordache', \\ Eugenia Ungureanu', Carmen Apostol', Gh. Enache', Dana Ispas ${ }^{1}$, Nicoleta Voicu-Pârvu', \\ D. Şerban ${ }^{1,2}$, Roxana Cebuc ${ }^{1}$, Alexandra Malciolu-Nica' ${ }^{1}$ Ana-Maria Dascălu ${ }^{1,2}$, \\ Emanoil Ceauşu ${ }^{1,2}$, Petre Calistru ${ }^{1,2}$ \\ ${ }^{1}$ Spitalul Clinic de Boli Infecţioase şi Tropicale „Dr. Victor Babeş“, Bucureşti, România \\ Universitatea de Medicină şi Farmacie "Carol Davila“, Bucureşti, România
}

\begin{abstract}
REZUMAT
Introducere. Începând cu anul 2016, România se confruntă cu o epidemie importantă de rujeolă apărută pe fondul unui procent tot mai scăzut de vaccinare. Evoluţia epidemiei a fost marcată şi de o creştere alarmantă a numărului de complicaţii şi decese.

Materiale şi metode. Am evaluat retrospectiv 632 pacienţi diagnosticaţi cu rujeolă, internaţi în Spitalul Clinic de Boli Infecţioase şi Tropicale „Dr. Victor Babeş“, în perioada ianuarie 2016 - decembrie 2017. Datele epidemiologice, caracteristicile clinice şi rezultatele probelor biologice au fost obţinute din fişele medicale ale pacienţilor.

Rezultate. Din cei 632 de pacienţi, $341(53,9 \%)$ au fost de sex masculin. Grupa de vârstă cea mai afectată a fost $1-4$ ani $(39,2 \%)$, urmată de cea a sugarilor cu un procent de $19,6 \%$.

O treime din cazuri $(31,3 \%)$ au avut contactul infectant în cadrul familiei. În ceea ce priveşte statusul vaccinal, aproape jumătate din pacienţi $(47,1 \%)$ nu au fost vaccinaţi, iar $44,3 \%$ nu cunoşteau istoricul de vaccinare (probabil nevaccinaţi sau incomplet vaccinaţi).

Complicaţiile virale au fost prezente la majoritatea pacienţilor $(84,1 \%)$ sub forma unei pneumonii interstiţiale. Pneumonia bacteriană a fost prezentă la $15 \%$ dintre pacienţi, iar dintre aceştia $45,2 \%$ au asociat şi insuficienţă respiratorie. Şase pacienţi au necesitat transfer în secţia de terapie intensivă pediatrie pentru suport respirator, înregistrându-se 2 decese.

Laringita a fost prezentă în $8,2 \%$ cazuri, otita în $12 \%$ cazuri, în timp ce $61,7 \%$ dintre pacienţi au avut afectare gastrointestinală.

Paraclinic, a fost evidenţiată citoliza hepatică la 101 (15,9\%) pacienţi şi diselectrolitemia a fost prezentă la $94(14,8 \%)$ din cazuri.

Concluzii. Studiul prezent arată creşterea alarmantă a incidenţei bolii şi a complicaţiilor sale în ultimii 3 ani, mai ales la vârstele mici. Considerăm imperios necesară aplicarea programului de vaccinare pentru a asigura o acoperire vaccinală optimă, utilă atât în stoparea epidemiei actuale, cât şi în prevenirea unor viitoare epidemii.
\end{abstract}

Cuvinte cheie: rujeolă, epidemie, complicaţii, deces, vaccinare

\section{INTRODUCERE}

Rujeola este o boală acută, extrem de contagioasă (indice de contagiozitate peste 95\%), determinată de infecţia cu virusul rujeolic (Morbillivirus, familia Paramyxoviridae). Transmiterea se face pe cale aeriană, prin picături respiratorii, boala răspândindu-se cu uşurinţă de la o persoană la alta prin tuse sau strănut.

Principalele simptome sunt reprezentate de febră şi exantem maculo-papulo-eritematos, însoţite 
de tuse, coriză şi afectare oculară. Primele simptome apar la aproximativ 10-11 zile după contactul cu o persoană bolnavă şi se manifestă prin febră, catar ocular şi respirator, iar ulterior, după 3-4 zile de la debutul acestora, apare rash-ul caracteristic cu distribuţie cranio-caudală.

Virusul rujeolic determină imunosupresie importantă, iar complicaţiile rujeolei afectează mai ales copiii cu vârstă până la 5 ani, persoanele imunodeprimate şi adulţii. Dintre complicaţii se remarcă pneumonia, encefalita, otita, gastroenterocolita şi laringo-traheo-bronşita. Panencefalita sclerozantă subacută este o complicaţie rară, dar foarte severă, ce apare la distanţă de episodul acut (cu o medie de 7 ani), cu degradare progresivă a sistemului nervos central, fiind letală în proporţie de $100 \%$.

În ultimii 3 ani, Europa şi implicit România s-au confruntat cu o epidemie de rujeolă, apărută pe fondul unui procent tot mai scăzut de vaccinare.

În anul 2016 au fost raportate 5.273 de cazuri de rujeolă în 53 de ţări europene. Numărul de cazuri a crescut de aproximativ 4 ori în anul 2017, când au existat 23.927 persoane din Europa infectate cu virusul rujeolic. Peste $75 \%$ dintre cazuri au fost înregistrate în prima jumătate a anului 2017, preponderent în lunile martie (2.802 cazuri), aprilie (2.472 cazuri) şi mai (2.244 cazuri) (1). România a fost cea mai afectată ţară din anul 2017 cu un total de 9.076 de cazuri raportate (2). Alte ţări care au raportat un număr alarmant de cazuri au fost Italia (peste 5.000 de cazuri), Grecia (967 cazuri), Germania (929 cazuri) şi Franţa (518 cazuri). Tot în anul 2017 au existat 37 de decese ale pacienţilor diagnosticaţi cu rujeolă, cele mai multe fiind în România (26 cazuri), urmată de Italia (4 cazuri) şi Grecia ( 2 cazuri).

Epidemia a continuat şi în anul 2018. Astfel, peste 41.000 de cazuri de rujeolă şi 37 de decese au fost raportate în prima jumătate a acestui an, fiind afectate 43 de țări din Europa. Franţa, Georgia, Italia, Rusia, Grecia, Ucraina şi Serbia s-au confruntat fiecare cu peste 1.000 de cazuri. În Germania au fost raportate 328 de cazuri, iar în Belgia, Bosnia şi Herţegovina au existat aproximativ câte 100 de cazuri. Cele mai multe cazuri de rujeolă au fost în Ucraina (peste 23.000), în timp ce în Serbia s-au înregistrat cele mai multe decese (14 cazuri) $(3,4)$.

Conform ultimului raport publicat de Institutului Naţional de Sănătate Publică, în România până octombrie 2018, numărul total de cazuri cu rujeolă raportate a fost de 15.395, dintre care 59 de decese. Vârful epidemiei de rujeolă a fost atins în luna martie 2017, când au fost înregistrate 1.338 cazuri. Ulterior, s-a observat o scădere a numărului de cazuri înregistrate săptămânal, de la 300, în perioada aprilie-iunie, la 50, în perioada septembrie-octombrie (2). Chiar şi în acest context, România încă se află în plină epidemie de rujeolă, din cauza acoperirii vaccinale insuficiente.

Obiectivul studiului de faţă a fost să evalueze cazurile de rujeolă internate într-un spital de boli infecţioase din Bucureşti şi să identifice caracteristicile socio-demografice, epidemiologice şi evoluția clinică a acestor pacienţi.

\section{MATERIALE ŞI METODE}

A fost realizat un studiu retrospectiv pe un lot de pacienţi diagnosticaţi cu rujeolă, în Spitalul Clinic de Boli Infecţioase şi Tropicale „Dr. Victor Babeş“ din Bucureşti, în perioada ianuarie 2016 - decembrie 2017.

Datele epidemiologice, caracteristicile clinice şi rezultatele probelor biologice au fost obţinute din fişele medicale ale pacienţilor şi din baza de date electronică a spitalului. Diagnosticul de rujeolă s-a stabilit pe baza datelor clinice şi a testelor serologice (anticorpi Ig M antirujeolă în plasmă) şi moleculare (PCR virus rujeolic din exsudatul nazo-faringian), respectiv în funcţie de caracteristicile epidemiologice (contact familial/colectivitate, status vaccinal).

\section{REZULTATE}

Numărul total de pacienţi diagnosticaţi cu rujeolă în perioada analizată a fost de 632, semnificativ mai mare în anul 2017 comparativ cu 2016 (604 vs. 28) (Fig 1). Incidenţa totală a fost 1,8\%(632/34.691), cu numeroase variaţii de-a lungul celor doi ani de studiu, de la $0,0 \%$ în perioada iulie-septembrie 2016 la 5,8\% în acelaşi interval al anului 2017 (Tabelul 1).

Din totalul de 632 pacienţi, 341 (53,9\%) au fost de sex masculin, iar 330 de pacienţi $(52,2 \%)$ proveneau din mediul urban. Mediana vârstei la momentul diagnosticului rujeolei a fost de 4 ani, cu un minim de 9 zile si maxim 49 de ani. Cei mai mulţi 


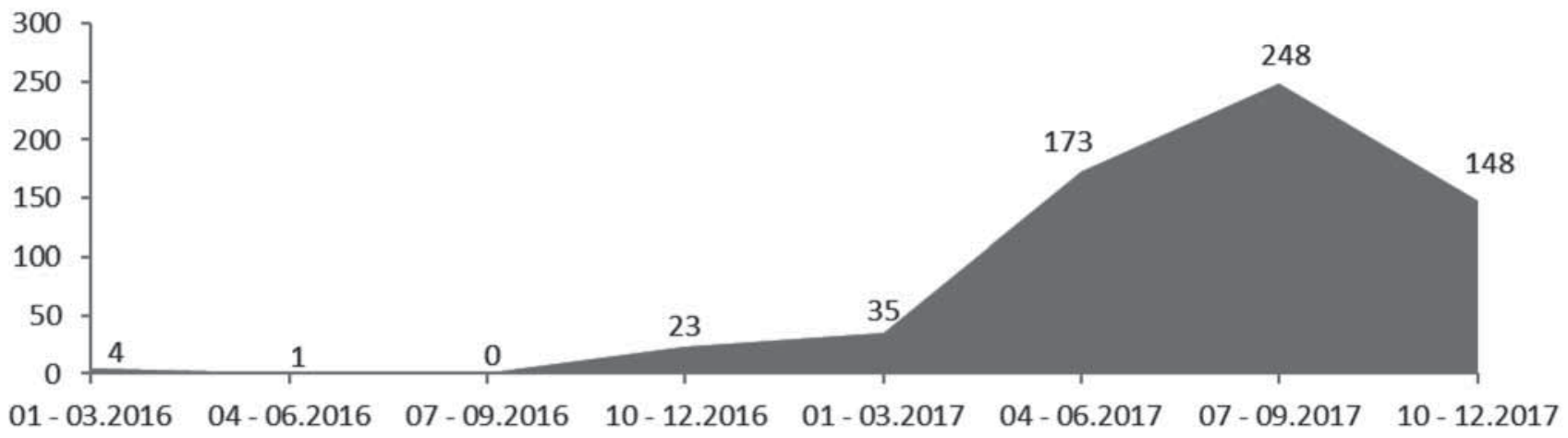

FIGURA 1. Distribuția temporală a numărului de cazuri de rujeolă

TABELUL 1. Distribuția temporală a incidenței rujeolei

\begin{tabular}{|l|c|c|c|c|c|c|c|c|}
\hline & \multicolumn{4}{|c|}{$\mathbf{2 0 1 6}$} & \multicolumn{4}{c|}{$\mathbf{2 0 1 7}$} \\
\hline Luna & $\mathbf{0 1 - \mathbf { 0 3 }}$ & $\mathbf{0 4 - \mathbf { 0 6 }}$ & $\mathbf{0 7 - 0 9}$ & $\mathbf{1 0 - 1 2}$ & $\mathbf{0 1 - \mathbf { 0 3 }}$ & $\mathbf{0 4 - \mathbf { 0 6 }}$ & $\mathbf{0 7 - 0 9}$ & $\mathbf{1 0 - 1 2}$ \\
\hline Nr. total bolnavi (n) & 4.729 & 5.799 & 4.372 & 4.105 & 4.438 & 4.429 & 4.260 & 4.014 \\
\hline Nr. total cazuri rujeolă (n) & 4 & 1 & 0 & 23 & 35 & 173 & 248 & 148 \\
\hline Incidența (\%) & 0,08 & 0,01 & 0,00 & 0,56 & 0,78 & 3,9 & 5,8 & 3,6 \\
\hline
\end{tabular}

pacienţi au avut vârsta cuprinsă între 1 şi 4 ani $(39,2 \%)$, iar $124(19,6 \%)$ erau sugari (tabelul 2).

TABELUL 2. Caracteristici socio-demografice ale pacienților diagnosticați cu rujeolă

\begin{tabular}{|l|c|l|}
\hline Caracteristici & & $\begin{array}{l}\text { Nr. total cazuri rujeolă } \\
\mathbf{N}=632\end{array}$ \\
\hline Sex masculin & $\mathrm{n}(\%)$ & $341(53,9)$ \\
\hline Mediul urban & $\mathrm{n}(\%)$ & $330(52,2)$ \\
\hline Vârsta la diagnostic (ani) & $\begin{array}{c}\text { Mediana } \\
\text { (interval) }\end{array}$ & $4(9$ zile, 49 ani) \\
\hline $\begin{array}{l}\text { Distribuția pe grupe de } \\
\text { vârstă }\end{array}$ & $\mathrm{n}(\%)$ & \\
$<1$ an & & $124(19,6)$ \\
$1-4$ ani & & $248(39,2)$ \\
$5-10$ ani & & $113(17,8)$ \\
$11-15$ ani & & $60(9,4)$ \\
$16-25$ ani & & $21(3,5)$ \\
$25-35$ ani & & $33(5,2)$ \\
$>35$ ani & &
\end{tabular}

În ceea ce priveşte caracteristicile epidemiologice, aproximativ jumătate dintre pacienţi, 317/632 $(50,1 \%)$, nu au avut un contact de rujeolă cunoscut, aproximativ o treime dintre pacienţi, 197/632 $(31,3 \%)$, au avut contact în familie, iar $70(11 \%)$ au contactat virusul în colectivităţi, dintre care 48/632 (7,5\%) în mediul spitalicesc.

În privinţa statusului vaccinal, 54/632 (8,5\%) pacienţi au declarat vaccinare incompletă, iar 298 pacienţi $(47,1 \%)$ nu au fost vaccinaţi. 280 pacienţi $(44,3 \%)$ nu cunoşteau istoricul de vaccinare (Tabelul 3).
TABELUL 3. Date epidemiologice ale pacienților diagnosticați cu rujeolă

\begin{tabular}{|l|l|l|}
\hline Caracteristici & & $\begin{array}{l}\text { Nr. total cazuri rujeola } \\
\mathrm{n}=632\end{array}$ \\
\hline Contact rujeolă & $\mathrm{n}(\%)$ & $197(31,3)$ \\
Mediu familial & & $48(7,5)$ \\
Mediu spitalicesc & $70(11,0)$ \\
Colectivitate & $317(50,1)$ \\
Necunoscut & $\mathrm{n}(\%)$ & $54(8,5)$ \\
\hline $\begin{array}{l}\text { Status vaccinare ROR* } \\
\text { Vaccinat incomplet }\end{array}$ & $298(47,1)$ \\
Nevaccinat & $280(44,3)$ \\
\hline Necunoscut & & \\
\hline *ROR= vaccin rubeolă, oreion, rujeolă \\
\hline
\end{tabular}

Diagnosticul paraclinic s-a stabilit cu ajutorul testelor serologice (IgM rujeolă), care au fost pozitive în cazul a 422 dintre pacienţi $(66,7 \%)$, în timp ce $72(11,3 \%)$ au avut test PCR din exsudatul nazofaringian pozitiv pentru virusul rujeolic.

Au fost 41 de pacienţi cu comorbidităţi (paraplegie flască, tetrapareză spastică, epilepsie, malformaţii cardiace, sindrom West, sindrom Down, boală pulmonară interstiţială cronică, insuficienţă cardiacă, glicogenoză tip IB, colită ulcerativă).

Pe parcursul evoluţiei bolii, au fost diagnosticate o serie de complicaţii asociate rujeolei. Marea majoritate a pacienţilor a asociat pneumonie interstiţială $(84,1 \%)$.

Suprainfecţia bacteriană a fost diagnosticată sub formă de pneumonie bacteriană în cazul a 95 (15\%) pacienţi. Dintre aceştia, 43/95 (45,2\%) au asociat şi 
insuficienţă respiratorie acută, majoritatea cu evoluţie favorabilă sub oxigenoterapie, corticoterapie şi antibioterapie cu spectru larg. Şase pacienţi au necesitat transfer în secţia de terapie intensivă pediatrie pentru intubare şi ventilaţie mecanică, dintre care 2 au avut evoluţie nefavorabilă cu deces (Tabelul 4).

Alte complicaţii infecţioase au fost: bronşiolita $(13,2 \%)$, laringita $(52,8,2 \%)$, otita $(76,12,0 \%)$, în timp ce $390(61,7 \%)$ au avut afectare digestivă (enterocolită).

$\mathrm{Nu}$ au fost diagnosticate cazuri de complicaţii neurologice la pacienţii evaluaţi.

Citoliza hepatică a fost prezentă la $101(15,9 \%)$ pacienţi. Diselectrolitemia în context intrainfecţios a fost identificată la $94(14,8 \%)$ dintre cazuri (Tabelul 5).

TABELUL 4. Evoluția pacienților cu insuficiență acută respiratorie asociată pneumoniei bacteriene apărute în cursul evoluției rujeolei

\begin{tabular}{|l|l|l|}
\hline Complicații & & $\begin{array}{l}\text { Nr. total cazuri } \\
\text { pneumonie bacteriană } \\
\text { n=95 }\end{array}$ \\
\hline Insuficiență respiratorie & $\mathrm{n}(\%)$ & $43(45,2)$ \\
\hline $\begin{array}{l}\text { Transfer în secția ATI cu IOT şi } \\
\text { ventilație mecanică }\end{array}$ & $\mathrm{n}(\%)$ & $6(6,3)$ \\
\hline Deces* & & $2(2,1)$ \\
\hline *în secția ATI pediatrie & & \\
\hline
\end{tabular}

TABELUL 5. Complicații asociate rujeolei

\begin{tabular}{|l|c|l|}
\hline Complicații & & $\begin{array}{l}\text { Nr. total cazuri rujeolă } \\
\text { n=632 }\end{array}$ \\
\hline Pneumonie interstițială & $\mathrm{n}(\%)$ & $532(84,1)$ \\
\hline Pneumonie bacteriană & $\mathrm{n}(\%)$ & $95(15,0)$ \\
\hline Bronşiolită & $\mathrm{n}(\%)$ & $13(2,0)$ \\
\hline Laringită & $\mathrm{n}(\%)$ & $52(8,2)$ \\
\hline Otită & $\mathrm{n}(\%)$ & $76(12,0)$ \\
\hline Enterocolită & $\mathrm{n}(\%)$ & $390(61,7)$ \\
\hline Citoliză hepatică & $\mathrm{n}(\%)$ & $101(15,9)$ \\
\hline Diselectrolitemie & $\mathrm{n}(\%)$ & $94(14,8)$ \\
\hline
\end{tabular}

\section{DISCUŢII}

Studiul prezent a fost efectuat pe un lot semnificativ de pacienţi diagnosticaţi cu rujeolă într-un spital de boli infecţioase din Bucureşti, România. Începând cu anul 2016, țara noastră s-a confruntat cu o epidemie de rujeolă care s-a extins alarmant pe fondul acoperirii vaccinale suboptimale din ultima decadă. Conform Institutului Naţional de Sănătate Publică, numărul cazurilor declarate de rujeolă din România a crescut de la 2.435 în 2016 la 9.076 în
2017. Similar, rezultatele studiului de faţă au evidenţiat acelaşi trend ascendent, cu o diferenţă semnificativă între numărul cazurilor raportate în 2017 faţă de anul precedent (2). Incidenţa rujeolei la pacienţii din spitalul nostru a crescut alarmant începând de la finalul anului 2016, atingând un maxim în perioada iulie-septembrie 2017 şi apoi urmând un trend uşor descendent.

Similar raportărilor din alte ţări, incidenţa bolii a variat în funcţie de grupele de vârstă, rujeola fiind diagnosticată predominant la copiii cu vârsta sub 10 ani, mediana vârstei la diagnostic fiind de 4 ani. Grupa de vârstă cel mai frecvent afectată a fost 1-4 ani, sugarii fiind infectaţi în proporţie mai mică, probabil datorită imunităţii restante de la mamă. Conform raportărilor Institutului Naţional de Sănătate Publică, grupa de vârstă 1-4 ani a fost cea mai afecatată la nivel naţional, fiind urmată de grupa de vârstă sub 1 an. Astfel, de la începutul epidemiei, numărul copiilor $\mathrm{cu}$ vârsta în acest interval a fost semnificativ mai mare comparativ cu alte grupe de vârstă.

În Grecia, în perioada mai 2017-martie 2018, a fost raportat un total de 2.099 cazuri de rujeolă. Dintre acestea, 69\% au fost diagnosticate la copiii cu vârsta sub 14 ani (6). În Italia, din totalul celor 5.098 de cazuri diagnosticate cu rujeolă în anul 2017, 68\% au avut vârsta peste 20 de ani. Ucraina s-a confruntat în primele luni ale acestui an cu o epidemie majoră de rujeolă, $66 \%$ dintre cazuri fiind diagnosticate la copii şi 34\% la adulţi (12). Regatul Unit al Marii Britanii a înregistrat 760 de cazuri de rujeolă în primele 7 luni ale anului 2018 la adolescenţi şi adulţi tineri, cel mai probabil ca o consecinţă a lipsei vaccinării (4).

Epidemia de rujeolă s-a răspândit pe fondul imunităţii precare împotriva virusului rujeolic. Apariţia acestei situaţii a fost favorizată de implementarea ineficientă a programelor de vaccinare. Un procent important din totalul pacienţilor lotului studiat au recunoscut vaccinare incompletă sau absentă. Aproximativ o treime dintre pacienţii noştri au avut contact în familie cu virusul rujeolic. Conform Organizaţiei Mondiale a Sănătăţii este necesar ca 95\% dintre persoanele eligibile să fie vaccinate cu 2 doze de vaccin anti-rujeolic pentru a preveni epidemia $(5,11)$. În 2016, în România, au fost înregistrate procente de $86 \%$ şi $76 \%$ în ceea ce priveşte rata vaccinării cu prima şi respectiv a doua 
doză (10). Ratele de vaccinare pentru cele două doze au variat de la o ţară la alta. Astfel, Italia a raportat rate de $87 \%$, respectiv $82 \%$, Franţa $90 \%$, respectiv $79 \%$, Grecia $97 \%$ şi $83 \%$. În Ucraina a fost înregistrată una dintre cele mai mici rate de imunizare la nivel mondial în anul 2016, doar 4\% dintre copii fiind vaccinaţi cu prima doză. Situaţia s-a îmbunătăţit în 2017, când 93,3\% dintre copii au primit prima doză de vaccin (9). Cu toate acestea, Ucraina s-a confruntat la începutul anului $2018 \mathrm{cu}$ cea mai mare epidemie de rujeolă raportată în Europa. Deşi Portugalia a înregistrat în anul 2016 rate ale vaccinării de $98 \%$ şi $95 \%$ pentru cele 2 doze, au fost raportate 34 de cazuri de rujeolă în perioada februarie-mai 2017 (8).

Virusul rujeolic are tropism respirator şi, în consecinţă, pacienţii asociază complicaţii atât la nivelul căilor respiratorii superioare, cât şi al celor inferioare, cel mai frecvent întâlnite fiind pneumoniile. Pneumoniile bacteriene diagnosticate la pacienţii noştri au avut în general evoluţie favorabilă, dar au fost înregistrate şi cazuri complicate cu insuficienţă respiratorie. Majoritatea acestor pacienţi erau taraţi, fiind diagnosticaţi şi trataţi anterior pentru diverse malformaţii şi afecţiuni: sindrom West, boală pulmonară interstiţială cronică, tetrapareză spastică, epilepsie, colită ulcerativă, malformaţie cardiacă, sindrom Down, paraplegie flască, glicogenoză tip IB. Dintre aceştia, 6 pacienţi au necesitat transfer în secţia de terapie intensivă pediatrie pentru suport respirator şi IOT cu ventilaţie mecanică. 2 copii au avut evoluţie nefavorabilă spre deces.

La nivel naţional, numărul deceselor înregistrate în context de rujeolă a fost de 13 în 2016, respectiv 26 în 2017, în prezent fiind raportate un total de 59 decese.

Cel mai mare număr de decese a fost raportat de Serbia în 2018 (14/1.778 cazuri) (13), în timp ce Ucraina a raportat în 2017 7/4.782 decese (12). În Italia, în perioada 2017-2018, au fost declarate $6 / 5.266$ decese. 2 decese au fost înregistrate în Franţa, unul în prima jumătate a anului 2017, dintre cele 518 cazuri raportate, iar cel de-al doilea în februarie 2018 (7). În perioada mai 2017-martie
2018, dintre cele 2.099 de cazuri raportate în Grecia, $3 \mathrm{~s}$-au finalizat cu deces.

La nivelul lotului analizat nu au fost identificate cazuri cu complicaţii neurologice, nefiind evidenţiat niciun caz de encefalită.

Deşi virusul rujeolic este serologic monotipic, în caracterizarea genetică a virusurilor tip sălbatic au fost identificate 8 clase (A-H). Acestea, la rândul lor, au fost divizate în 24 de genotipuri, clasele B, C, D, G, H conţinând multiple genotipuri. $\mathrm{Nu}$ au fost identificate diferenţe biologice între diferitele genotipuri. De asemenea, nu a fost găsită o asociere între un genotip specific, tipul de severitate al bolii şi probabilitatea de a dezvolta panencefalită sclerozantă subacută.

Teste moleculare pentru identificarea genotipului circulant nu se efectuează de rutină în ţara noastră. S-a realizat un număr foarte mic de genotipări la nivelul lotului studiat, rezultatele demonstrând apartenenţa acestora la genotipul B3. Aceasta confirmă datele din literatură, genotipul B3 fiind prevalent în România, similar Italiei sau Greciei, în timp ce genotipul D8 a fost identificat în Franţa sau Italia.

\section{CONCLUZII}

Incidenţa rujeolei a crescut alarmant în ultimii ani în România, afectând în special copiii cu vârsta între 1 şi 4 ani. Evoluţia clinică poate fi complicată de suprainfecţii bacteriene ce necesită uneori management în secţii de terapie intensivă, mai ales în cazul copiilor cu comorbidităţi asociate. În contextul globalizării actuale, cu mişcări mari de populaţii, eliminarea rujeolei este dificil de realizat în absenţa unui program riguros de vaccinare.

Implementarea programelor de vaccinare eficiente şi adoptarea de măsuri adecvate - pentru a creşte conştientizarea populaţiei asupra importanţei vaccinării copiilor şi a riscurilor la care sunt expuşi prin nerespectarea acestora - au o maximă importanţă în lupta pentru stoparea actualei epidemii de rujeolă şi prevenirea unei viitoare epidemii. 